\title{
Türk Dili ve Edebiyatı Öğretmeni Adaylarının Karakter ve Değerler Eğitimi Dersine Yönelik Görüşlerinin İncelenmesi
}

\author{
DOI: $10.26466 /$ opus.569630
}

Nurullah Șahin*

* Dr. Öğr. Üyesi, Ağrı İbrahim Çeçen Üniversitesi, Eğitim Fakültesi Ağrı / Türkiye E-Posta: nsahin.86@gmail.com ORCID: $\underline{0000-0002-3462-0369}$

\section{Öz}

Bu araştırmanın amacl; Türk dili ve edebiyatı öğretmeni adaylarının Karakter ve Değerler Ë̆itimi dersine yönelik görü̧̧lerini tespit etmektir. Nitel araştırma yaklaşımının benimsendiği çalışmada, betimsel tarama modeli kullanılmıştır. Araştırmanın çalışma grubunu 2018-2019 eğitim öğretim yılı güz yarıyılında, Sinop Üniversitesi Pedagojik Formasyon Programı'nda, seçmeli ders olarak Karakter ve Değerler Eğitimi dersini alan 35'i kadın ve 24'ü erkek olmak üzere toplam 59 öğretmen adayı oluşturmaktadır. Araştırmada veri toplama aracı olarak 5 adet açı uçlu sorudan oluşan yarı yapılandırılmış görüşme formu kullanılmıştır. Elde edilen verilerin çözümlenmesinde ise, betimsel analiz tekniğinden yararlanılmıştır. Elde edilen veriler öncelikle detaylı bir okumaya tabi tutulmuş ve kodlanmıştır. Sonrasında ise, kodlanan verilerin içeriği doğrultusunda her bir alt problem için kategoriler oluşturulmuştur. Araştırmanın bulgular kısmında; her bir alt problem için oluşturulan kategorilere yönelik bazı basit istatistiki bilgilerle birlikte, doğrudan alıntı yaparak kategorilerle ilgili öne çıkan bazı öğretmen adayı görüşlerine yer verilmiştir. Araştırmanın neticesinde; birinci alt probleme yönelik elde edilen sonuçlar incelendiğinde, Türk dili ve edebiyatı öğretmeni adaylarının \%50,84'ünün karakter ve değerler eğitimini, "bireyin dünyaya ve içinde bulunduğu topluma adapte olmasını sağlayan ve toplumu huzura ulaştıran bir eğitim süreci" olarak tanımladıkları görülmüştür. İkinci alt probleme yönelik ulaşılan sonuçlara bakıldığında; katılımcıların \%35,59'luk bölümü, "dersin kişisel gelişimine katkı sağlayacağı düşüncesi" sebebiyle Karakter ve Değerler Ĕ̆itimi dersini seçtiklerini ifade etmişlerdir. Çalışmanın üçüncü alt problemine yönelik elde edilen sonuçlar incelendiğinde; öğretmen adaylarının \%76,27'lik gibi büyük bir bölümünün Karakter ve Değerler Eğitimi dersinin lisans programlarında kesinlikle yer alması gerektiğini düşündükleri görülmüştür. Son olarak araştırmanın beşinci alt problemine yönelik sonuçlar incelendiğinde, katılımcıların \%71,18'lik gibi büyük bir bölümünün Karakter ve Değerler Eğitimi dersinin değerlendirme ölçütlerinin neler olması gerektiğine dair, "okul, aile ve sosyal hayatta; öğrencilerin davranışlarında ve tutumlarında meydana gelen değişiklikler dikkate alınmalı" şeklinde görüş belirttikleri görülmüştür.

Anahtar Kelimeler: Değer, Karakter ve Değerler Eğitimi dersi, Türk dili ve edebiyatı öğretmeni adaylart 


\title{
Examination of The Views of Turkish Language and Literature Teacher Candidates on Character and Value Education Course
}

\begin{abstract}
The aim of this study is to determine the views of Turkish language and literature teacher candidates about the Character and Value Education course. The descriptive survey model was used in the study, in which the qualitative research approach was adopted. The study group consists of 59 teacher candidates (35 females and 24 males), who chose the Character and Value Education course as an elective course in the Pedagogical Formation Program of Sinop University in the fall semester of 2018-2019 academic year. In this study, a semi-structured interview form consisting of 5 open-ended questions was used as a data collection tool. Descriptive analysis technique was used to analyze the data obtained. Firstly, the data obtained were read and coded in detail. Then, categories were formed for each subproblem according to the content of the data encoded. The results section of the study included some simple statistical information related to the categories created for each sub-problem, as well as the views of some teacher candidates who stood out regarding the categories by citing from them directly. As a result of this study, when the results of the first sub-problem were examined, it was seen that $50.84 \%$ of Turkish language and literature teacher candidates defined character and values education as an education process that enables the individual to adapt to the world and the society in which he or she lives ". Based on the results of the second sub-problem, $35.59 \%$ of the participants stated that they selected the course of character and values education because of the idea that the course would contribute to their personal development. When the results of the study were examined for the third sub-problem, it was observed that a large part of the teacher candidates, such as $76.27 \%$, thought that the course of character and values education should be included in the undergraduate programs. Finally, when the results of the fifth sub-problem of the study were examined, $71.18 \%$ of the participants stated that the evaluation criteria of the Character and Values Education course should be "in school, family and social life; changes in students' behaviors and attitudes should be taken into consideration"
\end{abstract}

Keywords: Value, character and value education, Turkish language and literature teacher candidates. 


\section{Giriş}

Değer kavramı, bilim insanlarının uzun yıllardan beri üzerinde düşündüğü ve araştırmalar yaptığı bir konu olmasına rağmen, özellikle son yıllarda değer ve değer eğitimi gibi konular gittikçe daha da popüler bir hâle gelmektedir. Günümüz toplumlarının başta ahlak olmak üzere inanç, tarih, maneviyat, millî bilinç $v b$. alanlarda yaşadığı çöküş ve toplumların genetik kodlarını yani kadim değerlerini gelecek kuşaklarına da aktarabilme kaygısı; değer konusunun popüler olması ve üzerinde çokça düşünülmesi zorunluluğunu da beraberinde getirmiştir.

Değer kavramı, birey ve toplum ilişkilerinde belirleyici ve yönlendirici etkiye sahiptir. Yani değerler, bireyin toplumun kadim kurallarına uygun biçimde yetişmesinin teminatıdır. Değerlerin, birey toplum ilişkileri ve bireylerin davranışları üzerindeki etkisi ile ilgili olarak bilim adamlarının söyledikleri manidardır. Örneğin; değerlerin, bireyin davranışları üzerindeki etkisine dikkat çeken Beil'e göre; "Değerler, bireylerin kendileri ve başkalarıyla ilgili davranışlarına yön verip, davranış kılavuzu görevi yapmaktadır. Her birey kendisi için önemli sayılan değerler için çaba sarf etme olanağına sahiptir. Herkes sosyal çevresinde hangi davranışın daha geçerli olduğuna hangisinin geçersiz olduğuna ilişkin önceden belirlenmiş yerleşmiş değer yargıları ile karşılaşır. Bireyler toplumsal kurallar, gelenek ve görenekler yoluyla 'iyi' ve 'kötüyü', 'doğru' ve 'yanlışı' ayırt ederek kendi ahlak ilkeleri doğrultusunda bir ölçü edinmeyi öğrenirler" (Beil, 2003, s.13-14).

Değer kavramına toplum açısından bakarak yola çıkan Alyılmaz ve Alyılmaz ise, değerlerin toplumun bireylerini bir araya getirici ve bir arada tutucu özelliğinden bahsederek "Toplumların oluşumunda ve birlikteliklerinde ortak değerlerin rolü büyüktür. Ortak değerler, ortak yaşayış ve inanışın, amaç ve ihtiyaçların ürünüdür" (2014, s.77) ifadelerini kullanmışlardır. Konunun biraz daha detaylarına değinen Semra Alyılmaz, aşağıdaki açıklamalara yer verir:

"Sistemler üstü bir sistem ve mükemmel bir varlık olarak yaratılmışlığın bilincinde olan insanoğlunun iyi, güzel, doğru, mutlu ve huzurlu bir yaşam sürmesi bir anlamda içinde yaşadığ Nitekim insanı temel, toplumsal ve evrensel değerlerle bütünleştirip bireysel ve toplumsal huzura kavuşturacak, aynı zamanda seçkin ve aydın 
kılacak etmenlerin başında içinde yaşadığı toplumun değerleri / değer yargiları gelir" (2008, s.137).

Günümüz dünyasında yaşayan toplumların en büyük sorunlarından biri de varlığını ve kültürünü geleceğe taşıma meselesidir. Kendi kültür ve değerlerini genç nesillerine aktarmayı başaran toplumlar ancak gelecekte var olmayı ve kendi bekaların teminat altına alabilmeyi başarabileceklerdir. Bu durum Er (2017) tarafından şu şekilde ifade edilmiştir: “... kültürden kaynaklı değişim ve ilerleme toplumu da etkiler. İnsanlar çok zengin olabilirler, çok dil bilebilirler, çok çeşitli kültürleri görebilirler; ancak onlar kendi değerlerini korudukça ve gelecek kuşaklara taşıdıkça var olabilirler. Çağdaşlıkta bunu gerektirmektedir" (Er, 2017, s.1179).

Tüm bu sebeplerle değer eğitimi toplumların geleceğini doğrudan etkileyen önemli bir mesele olarak karşımıza çıkmaktadır. Konuyla ilgili olarak Doğan, "Bir ülkenin eğitim sistemi o ülkenin önem verdiği ve eğitim sistemine de yansımış olan değerlerle başlar. Bu değerler eğitimin çerçevesini, amaçlarını ve yönünü belirler" (Doğan, 1997, s.18) tespitini yapmıştır. Kültürün ve değerlerin geleceğe taşınmasının önemi hakkında Köktürk ise şu ifadelere yer vermiştir:

"Din, hukuk, devlet, ahlak, bilim, dil edebiyat, sanat, ekonomi ve teknik vasitalar kültür objeleridir ve nakledilebilir mülkiyetlerdir. Kültür olgusu olmanın kıstası, onlara sinmiş olan değerlerin toplumun üyeleri tarafından geçerli kabul edilmesidir. Bu geçerlilik talebi ve gereği toplumun sonraki kuşaklarını da kapsar. Dolayısıyla yansıyan ya da nakledilen şey, aslında 'değerler'dir" (Köktürk, 2006, s.274).

Konuyla ilgili olarak Kavcar'ın çağdaş eğitimin amacını da ifade ettiği görüşleri şöyledir:

“En geniş ve genel anlamıyla eğitim, çocuk olsun, genç olsun, yaşlı olsun, insanlarda sosyal hayata ve çağa uygun tutum ve davranış değişikliği sağlamaktır. Eğitimin işlevi topluma sağlıklı bir biçimde uyum yapabilmeleri için insanları etkilemektir. Bu etkileme, geçmişteki sosyal ve ulusal değerleri tanıtıp benimsetme, bugünün gerçeklerini gösterme ve geleceğe dönük değerler, hünerler kazandırma yoluyla olur. Çağdaş eğitimin amacı, dünü koruyarak yarını güven altına almaktır... Kısacası eğitimden beklenen üç esas; dünü tanıtma, bugünü kavratma ve yarına hazırlamadır" (Kavcar, 1999, s.1). 
Değer eğitiminin hayati bir önem arz ettiği böyle bir düzlemde eğitimcilere önemli sorumluluklar düşmektedir.

Eğitimin birincil amaçları arasında yer alan kültürü ve değer yargılarını bir sonraki nesle aktarma işi, öncelikle hangi değerlerin aktarılacağının, bu değerlerin nasıl aktarılacağının, bu süreçte eğitimcilerin sahip olması gereken niteliklerin ve davranışların nasıl olması gerektiğinin tespit edilmesiyle yakından ilgilidir. Bu nedenle sağlıklı bir değer öğretimi programına ve sürecine ihtiyaç vardır (Şahin, 2017, s. 60).

Çağdaş insanın yaşadığı bunalımlar ve çıkmazlar, günümüzde değer eğitiminin önem kazanmasının başka bir sebebi olarak gösterilebilir. Nitekim değerlerden yoksun bir şekilde sürülen hayatlar sadece kendilerini değil, içinde yaşadıkları toplumu da uçuruma sürüklemektedirler. Bu perspektiften bakıldığında Kale (2004, s.319), değerler eğitiminin amacını şöyle ifade etmektedir:

“Bireyleri evrensel (etik) ve kültürel değerlere ve bunların önemine ilişkin bilinçlendirmek, demokratik tutumlarla, hoşgörüyle çok kültürlülüğü ilişkilendirmek, naturalist bir hümanizmi vurgulamak, tüm değerleri insanın varlık şartları ve olanaklarını geliştirme ölçütüyle değerlendirmek, etik değerlere ilişkin somut problemlerden hareketle hayatı bilgiye ve / veya bilgiyi hayata dönüştürmek."

Bütün bu nedenlerden sonra açık bir şekilde ifade edilebilir ki; değerler eğitimi, "eğitimin her kademesinde yer almalı ve buna yönelik son derece hassas bir şekilde oluşturulmuş öğretim programları ve eğitim süreçleri hazırlanmalıdır" (Şahin, 2017, s.61).

\section{Araştırmanın Amacı}

Bu çalışmada, Türk dili ve edebiyatı öğretmeni adaylarının Karakter ve Değerler Eğitimi dersine yönelik görüşlerini tespit etmek amaçlanmıştır. $\mathrm{Bu}$ amaç doğrultusunda çalışmanın alt problemleri aşağıdaki şekilde belirlenmiştir:

1. Türk dili ve edebiyatı öğretmeni adayları, karakter ve değerler eğitimini nasıl tanımlamaktadırlar?

2. Türk dili ve edebiyatı öğretmeni adaylarının Karakter ve Değerler Eğitimi dersini seçme amaçları nelerdir? 
3. Türk dili ve edebiyatı öğretmeni adaylarının Karakter ve Değerler Eğitimi dersinin üniversitelerde lisans programlarında yer almasına ilişkin görüşleri nelerdir?

4. Türk dili ve edebiyatı öğretmeni adaylarının okullarda (ilkokul, ortaokul, lise), karakter ve değerler eğitimine yönelik eğitsel faaliyetlere yer verilmesine ilişkin görüşleri nelerdir?

5. Türk dili ve edebiyatı öğretmeni adaylarına göre; Karakter ve Değerler Eğitimi dersinin değerlendirme ölçütleri neler olmalıdır?

\section{Yöntem}

\section{Çalışmanın Deseni}

Türk dili ve edebiyatı öğretmeni adaylarının Karakter ve Değerler Eğitimi dersine yönelik görüşlerinin araştırıldığı bu çalışmada, nitel araştırma yaklaşımlarından betimsel tarama modeli kullanılmıştır. Naturalistik paradigmaya dayanan betimsel tarama çalışmaları (Qualitative Descriptive Study); olgubilim, gömülü teori, etnografi çalışmalarından farklı olarak verinin derinlemesine incelenmediği ve yorumlanmadığı, sadece görüşme, gözlem, doküman analizi yöntemleri ile sosyal olay ve olguların olduğu gibi değiştirilmeden ortaya konulduğu tasvir çalışmalarıdır (Arslantürk ve Arslantürk, 2013; Lambert ve Lambert, 2012; Walker, 2012).

\section{Çalışma Grubu}

Çalışma, 2018-2019 eğitim öğretim yılı güz dönemi içerisinde Sinop Üniversitesi Pedagojik Formasyon Programı'nda öğrenim görmekte olan ve seçmeli ders olarak Karakter ve Değerler Eğitimi dersini seçen 59 öğrenci ile gerçekleştirilmiştir. Öğrencilerin cinsiyet değişkenine göre dağılımı Tablo 1'de verilmiştir.

Tablo 1. Çalışma Grubunun Cinsiyet Değişkenine Göre Dağılımlan

\begin{tabular}{lll}
\hline Cinsiyet & f & \% \\
\hline Kadın & 35 & 59,32 \\
\hline Erkek & 24 & 40,67 \\
\hline Toplam & 59 & 100 \\
\hline
\end{tabular}




\section{Verilerin Toplama Araçları}

Araştırmada veri toplama aracı olarak 5 adet açlk uçlu sorudan oluşan yarı yapılandırılmış görüşme formu kullanılmıştır. Görüşme formunda aşağıdaki sorulara yer verilmiştir:

1. Karakter ve değerler eğitimini nasıl tanımlarsınız?

2. Karakter ve Değerler Eğitimi dersini seçme amacınız nedir?

3. Karakter ve Değerler Eğitimi dersinin üniversitelerde, lisans programlarında yer alması ile ilgili görüşleriniz nelerdir?

4. Okullarda (ilkokul, ortaokul, lise), karakter ve değerler eğitimine yönelik eğitsel faaliyetlere yer verilmesi ile ilgili görüşleriniz nelerdir?

5. Karakter ve Değerler Eğitimi dersinin değerlendirme ölçütleri sizce neler olmalıdır?

\section{Verilerin Analizi}

Çalışmada veri analiz yöntemi olarak betimsel analiz tekniği kullanılmıştır. Yıldırım ve Şimşek'e (2005) göre; betimsel analiz tekniğinde, sık sık doğrudan alıntılara yer verilir. Analizler neticesinde elde edilen veriler, frekans ve yüzdelik analizler ile dikkatlere sunulmuştur. Ayrıca betimsel analizin doğasına uygun olacak şekilde, verilerin analizi neticesinde oluşan kategorilere ilişkin doğrudan alıntılara yer verilmiştir. Doğrudan alıntılara yer verilirken 59 Türk dili ve edebiyatı öğretmeni adayının ismi, ÖA-1, ....., ÖA-59 aralığında kodlanmıştır.

Araştırmada öğretmen adaylarının 5 adet açık uçlu soruya verdikleri cevaplar, eş zamanlı olarak hem araştırmacı hem de Ağrı İbrahim Çeçen Üniversitesi Eğitim Fakültesi Türkçe ve Sosyal Bilimler Eğitimi Bölümünde görev yapmakta olan bir doktor öğretim üyesi tarafından analiz edilerek kodlar ve kategoriler oluşturulmuştur. Süreç sonunda üzerinde görüş birliği sağlanan kodlar aynen bırakılmış, görüş ayrılıklarının yaşandığı yerlerde ise ortak bir görüş birliği sağlanacak şekilde konu üzerinde karşılıklı tartışılmış ve yeni düzenlemeler yapılmıştır. Bu doğrultuda gerçekleştirilen analizin güvenliğini test etmek için Miles ve Huberman (1994) tarafından önerilen formül kullanılmış, 
araştırmanın güvenirlik düzeyi ortalama olarak \%92 olarak tespit edilmiştir.

\section{Bulgular}

\section{Araştırmanın Birinci Alt Problemine İlişkin Bulgular}

Bu bölümde; Türk dili ve edebiyatı öğretmeni adaylarının, karakter ve değerler eğitimini nasıl tanımladıklarını tespit etmek amaçlanmıştır. Bu bağlamda öğretmen adaylarından elde edilen verilerin analizi neticesinde 4 farklı kategori oluşturulmuştur. İlgili kategoriler ve bunlara ilişkin sonuçlar aşağıdaki tabloda gösterilmiştir:

Tablo 2. Türk dili ve edebiyatı öğretmeni adaylarnın karakter ve değerler eğitimini nasıl tanımladıklarına yönelik görüşlerinin analizi neticesinde ulaşılan kategoriler

\begin{tabular}{|c|c|c|c|}
\hline & Kategoriler & $f$ & $\%$ \\
\hline \multirow{5}{*}{$\begin{array}{l}\text { Karakter } \\
\text { ve değerler } \\
\text { eğitimini } \\
\text { nasıl } \\
\text { tanımlarsınız? }\end{array}$} & $\begin{array}{l}\text { Kimliğimizi ve benliğimizi korumanın ol- } \\
\text { mazsa olmaz yolu }\end{array}$ & 10 & 16,94 \\
\hline & $\begin{array}{l}\text { Bireyin dünyaya ve içinde bulunduğu top- } \\
\text { luma adapte olmasını sağlayan ve toplumu } \\
\text { huzura ulaştıran bir eğitim süreci }\end{array}$ & 30 & 50,84 \\
\hline & $\begin{array}{l}\text { İnsanın sahip olması gereken ahlaki ve vicdani } \\
\text { bazı değerlerin öğretimi süreci }\end{array}$ & 18 & 30,50 \\
\hline & $\begin{array}{l}\text { İnsanı her yönüyle değerlendirme noktasında } \\
\text { yeterli olmayan ve sadece ideali dile getiren bir } \\
\text { yaklaşım }\end{array}$ & 1 & 1,69 \\
\hline & Toplam & 59 & 100 \\
\hline
\end{tabular}

Tablo 2 incelendiğinde Türk dili ve edebiyatı öğretmeni adaylarının $\% 50,84$ 'ü karakter ve değerler eğitimini; “bireyin dünyaya ve içinde bulunduğu topluma adapte olmasını sağlayan ve toplumu huzura ulaştıran bir eğitim süreci" olarak tanımlamaktadırlar. Bu doğrultuda öne çıkan bazı öğretmen adayı görüşleri aşağıda dikkatlere sunulmuştur:

- ÖA-2: Karakter ve değerler eğitimi; evrensel olarak insanın toplum içinde bireysel olarak var olabilmesi için gerekli olan eğitimdir.

- ÖA-5: Bireylerin kişiliklerinin gelişmesi, bireye toplumsal değer ve normlar kazandırılması için verilen eğitimdir. Bu eğitimle birey kendi yaşantısını ve toplumsal yaşantıyı geliştirir. Topluma faydalı bireyler yetişir. 
Tablo 2'ye dönüldügünde Türk dili ve edebiyatı öğretmeni adaylarının \%30,50'sinin karakter ve değerler eğitimini; "insanın sahip olması gereken ahlaki ve vicdani bazı değerlerin öğretimi süreci” olarak tanımladığı görülmektedir. Bu bağlamda bazı öğretmen adayı görüşleri aşağıda verilmiştir:

- ÖA-53: Karakter ve değerler eğitimi insanın iç yapısına hitap eden davranışların yönlendiren bir eğitimdir. Bu eğitimle insanlar gerek kültür gerekse yaşamındaki değerleri ortaya koyan, insanları zorlamak yerine değil de vicdanı ve iç sesine bırakan ve insanın bu değerlere uyduğunda mutluluk, haz almasinı sağlayan bir eğitimdir....

- $\quad$ ÖA-54: Bu eğitim ilim ve fenden de bence önemlidir. Başarıl ama ahlaksız öğretmenlerin yetiştireceği öğrenciler toplum için felaket olur. Ya da zeki bir bilim adamının tüm evrensel değerleri yok sayarak insan katli için silahlar üretmesi. Yabanci siyasetçilerin yetişmesi gibi. Her şeyden önce karakter ve ahlak önemli.

Tablo 2 incelenmeye devam edildiğinde; Türk dili ve edebiyatı öğretmeni adaylarının \%16,94'ünün karakter ve değerler eğitimini; "kimliğimizi ve benliğimizi korumanın olmazsa olmaz yolu" olarak tanımladığı görülmektedir. Bu bağlamda bazı öğretmen adayı görüşleri aşağıda verilmiştir:

- ÖA-10: Karakter ve değerler eğitimi, aslında kaybetmeye başladığımız gerek insani gerekse millî değerlerin eğitim yoluyla tekrar kazandırılmaya, farkına varılmaya ve kalıcılık sağlamaya çalışılmasıdır.

- ÖA-19: Karakter ve değerler eğitimi geçmişten günümüze gelen ve hala devam etmekte olan değerlerimizi diri tutmaya yardımcı olan eğitimdir. Karak-

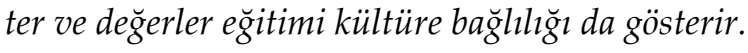

Tablo 2'de; Türk dili ve edebiyatı öğretmeni adaylarının \%1,69'unun karakter ve değerler eğitimini; "insanı her yönüyle değerlendirme noktasında yeterli olmayan ve sadece ideali dile getiren bir yaklaşım" olarak tanımladığ1 görülmektedir. Bu kategoride sadece bir öğretmen adayının görüşü yer almaktadır ki; o görüş, aşağıda verilmiştir:

- ÖA-36: Insanı her yönü ile ele alan değil de olması gerekeni ele alan bir eğitim türüdür. 


\section{Araştırmanın İkinci Alt Problemine İlişkin Bulgular}

Bu bölümde; Türk dili ve edebiyatı öğretmeni adaylarının, Karakter ve Değerler Eğitimi dersini seçme amaçlarını tespit etmek hedeflenmiştir. Bu bağlamda öğretmen adaylarından elde edilen verilerin analizi neticesinde 7 farklı kategori oluşturulmuştur. İlgili kategoriler ve bunlara ilişkin sonuçlar aşağıdaki tabloda gösterilmiştir:

Tablo 3. Türk dili ve edebiyatı öğretmeni adaylarının Karakter ve Değerler Ĕ̆itimi dersini seçme amaçlarının analizi neticesinde ulaşılan kategoriler

\begin{tabular}{llll}
\hline & Kategoriler & $f$ & \% \\
\hline & $\begin{array}{l}\text { Mesleki gelişimine katkı sağlama ve öğretmenlik } \\
\text { hayatında kendi öğrencilerine faydalı olma dü- } \\
\text { şüncesi }\end{array}$ & \multicolumn{2}{c}{33,89} \\
\cline { 2 - 4 } $\begin{array}{l}\text { Karakter } \\
\text { ve Değerler }\end{array}$ & $\begin{array}{l}\text { Dersin kişisel gelişimine katkı sağlayacağı dü- } \\
\text { şüncesi }\end{array}$ & 21 & 35,59 \\
\cline { 2 - 4 } $\begin{array}{l}\text { Eğitimi } \\
\text { dersini seçme } \\
\text { amacınız } \\
\text { nedir? }\end{array}$ & $\begin{array}{l}\text { Dersin isminin ilgi çekici olması ve içeriğine yö- } \\
\text { nelik merak duygusu }\end{array}$ & 9 & 15,25 \\
\cline { 2 - 4 } & Dersin önemine ve gerekliliğine olan inanç & 6 & 10,16 \\
\cline { 2 - 4 } & Arkadaşlarının da bu dersi seçmiş olması & 1 & 1,69 \\
\cline { 2 - 4 } & Kolay bir ders olduğunu düşünme & 1 & 1,69 \\
\cline { 2 - 4 } & Dersi tesadüfi bir şekilde seçme & $\mathbf{5 9}$ & $\mathbf{1 0 0}$ \\
\cline { 2 - 4 } & Toplam & & \\
\hline
\end{tabular}

Tablo 3 incelendiğinde; Türk dili ve edebiyatı öğretmeni adaylarının \%35,59'unun Karakter ve Değerler Eğitimi dersini, “dersin kişisel gelişimine katkı sağlayacağı düşüncesi" sebebiyle seçtikleri görülmektedir. Bu doğrultuda öne çıkan bazı öğretmen adayı görüşleri aşağıda dikkatlere sunulmuştur:

- ÖA-6: Derse olan ilgim ve bazı konularda tek görüşlü olmam. Bu yüzden yaşadığım sikıntılarım ve yıkmam gereken tabularım olduğunun farkına vardım. Bu ders ve konularının bana olan katkısını göz önünde bulundurarak seçim yaptım.

- ÖA-37: Değerleri doğru anlayabilmek ve bunları davranışlarımda gösterebilmeyi să̆lamak amactyla seçtim.

Tablo 3'e dönüldügünde Türk dili ve edebiyatı öğretmeni adaylarının \%33,89'unun Karakter ve Değerler Eğitimi dersini, "mesleki gelişimine katkı sağlama ve öğretmenlik hayatında kendi öğrencilerine faydalı olma 
düşüncesi" sebebiyle seçtikleri görülmektedir. Bu bağlamda bazı öğretmen adayı görüşleri şöyledir:

- ÖA-2: Dersi seçme amacım; birey karakterini tanıyabilme yetisini bana kazandıracağını düşünmüş olmamdır. Öğrenciyi tanıyabilmek ve böylece ona tam manasıyla yardımcı olabilmek benim için önemlidir.

- ÖA-10: Bu dersin bana çok şey katacă̆ı düşüncesindeydim. Öğretmen olmak için aldığımız eğitimler ilerideki öğrencilerimizi etkileyecek unsurlardır. Öyle ki; Karakter ve Değerler Eğitimi dersi de sahip olduğumuz değerlerin önemini nasıl aktaracağım ve onlara değer bilincini nasıl aşılayacağım hususunda yardımcı olacă̆̆nı düşündüğ̈̈̈m için seçtim.

Tablo 3'te; Türk dili ve edebiyatı öğretmeni adaylarının \%15,25'inin Karakter ve Değerler Eğitimi dersini, "dersin isminin ilgi çekici olması ve içeriğine yönelik merak duygusu" sebebiyle seçtikleri görülmektedir. Bu doğrultuda öne çıkan bazı öğretmen adayı görüşleri şöyledir:

- ÖA-12: Değerlerimize sahip çıkan ve önem veren bir toplumuz. Dersin isminin yaşamımızla olan benzerliğinin ilgimi çekmesi dersi seçmeme sebep, merak etmem de bu dersi seçmeme amaç oluşturdu.

- ÖA-45: Karakter kavramı çok dikkatimi çekmişti. Daha sonra "Insan karakterine göre mi değer benimser?" sorusunu aklıma getirdi. Çok merak uyandırdığı için bu dersi seçtim.

Tablo 3 incelenmeye devam edildiğinde; Türk dili ve edebiyatı öğretmeni adaylarının \%10,16'sının Karakter ve Değerler Eğitimi dersini, “dersin önemine ve gerekliliğine olan inanç" sebebiyle seçtikleri görülmektedir. Bu kategoride yer alan bazı öğretmen adayı görüşleri aşağıda dikkatlere sunulmuştur:

- ÖA-16: Bu dersin bana çok katkı sağlayacağını düşündü̆̆̈̈m için seçtim. Çünkü herkesin alması gereken bir ders olduğunu düşünüyorum. Ülkemizde çoğu insan değerlerini kaybetmektedir. Her yıl birbirinden farklı olumsuzluk olmaktadır. Hırsızlık, yolsuzluk oranları artmış bulunmaktadır. Insanların bazı konularda bilinçlenmesi ve değerlerini kaybetmemesi gerektiğini düşünüyorum. Ne yazık ki birçok insan, insan olduğunu unutmuştur.

- ÖA-57: Bu dersi seçme amacım toplumsal değerlere önem vermem gerektiğ $i$ bilincinde olmam. Çünkü bir toplumun birliği ve devamlılığını sağlaması, kahıılığını koruması değerlerine sahip çıkmasıyla mümkün olacaktır.

Tablo 3'te Türk dili ve edebiyatı öğretmeni adaylarının \%1,69'unun Karakter ve Değerler Eğitimi dersini, “arkadaşlarının da bu dersi seçmiş 
olması" sebebiyle seçtiği görülmektedir. Bu kategoride sadece 1 öğretmen adayı görüşü yer almaktadır ve bu görüş aşağıda verilmiştir:

- ÖA-20: Bu dersi arkadaşlarımında seçmesi.

Tablo 3'e göre; Türk dili ve edebiyatı öğretmeni adaylarının $\% 1,69$ 'unun Karakter ve Değerler Eğitimi dersini, "kolay bir ders olduğunu düşünmesi" sebebiyle seçtiği görülmektedir. Bu kategoride sadece 1 öğretmen adayı görüşü yer almaktadır ve bu görüş aşağıda dikkatlere sunulmuştur:

- ÖA-29: Bilinçli olarak seçmedim. Seçenekler arasında en makul olanıydı. Zor bir ders olmayacağıı düşündüm çünkü. Dersin içeriği hakkında bir fikrim yoktu.

Son olarak Tablo 3'e bakıldığında; Türk dili ve edebiyatı öğretmeni adaylarının \%1,69'unun Karakter ve Değerler Eğitimi dersini, "dersi tesadüfi bir şekilde seçtiği" görülmektedir. Bu kategoride sadece 1 öğretmen adayı görüşü yer almaktadır ve bu görüş şöyle ifade edilmiştir:

- ÖA-59: Bu dersi seçmem biraz tesadüfi oldu. Seçtikten sonra derse olan ilgi ve beklentim artmış, küllenmeye yüz tutmuş olan değerleri sahip çıkmaya, onları uygulama isteği arzu oluştu.

\section{Araştırmanın Üçüncü Alt Problemine İlişkin Bulgular}

Bu bölümde; Türk dili ve edebiyatı öğretmeni adaylarının, Karakter ve Değerler Eğitimi dersinin üniversitelerde lisans programlarında yer alması ile ilgili görüşlerini tespit etmek amaçlanmıştır. Bu bağlamda öğretmen adaylarından elde edilen verilerin analizi neticesinde 4 farklı kategori oluşturulmuştur. İlgili kategoriler ve bunlara ilişkin sonuçlar aşağıdaki tabloda gösterilmiştir:

Tablo 4 incelendiğinde; Türk dili ve edebiyatı öğretmeni adaylarının \%76,27'sinin Karakter ve Değerler Eğitimi dersinin üniversitelerde lisans programlarında yer almasına yönelik "evet, kesinlikle yer alması gerektiğini düşünüyorum" şeklinde görüş belirttikleri görülmektedir. Bu doğrultuda öne çıan bazı öğretmen adayı görüşleri aşağıda dikkatlere sunulmuştur:

- ÖA-3: Çok gerekli bir derstir. Günümüzde çoğu insan karaktere ve değerlere önem versede yaş ilerledikçe başka düşüncelerin heyecanına kapılarak bildiği 
halde bu değerleri unutabilir ve uygulamayabilir. Değerlerin canlı tutulması için üniversitelerde yer alması gereklidir.

- ÖA-10: Kafamizda Karakter ve Değerler Ĕgitimi dersinin yalnizca ilkokul, ortaokul ve liselerde alınması gerektiği düşüncesi oluşmakta ilk başta fakat kesinlikle üniversite lisans programlarında yer almalıdır. Çünkü değer eğitiminin alınmasının bir yaş sınır bulunamaz ki zamanla her insan gerek yaşadıklarıyla gerekse gördükleriyle bazı değerlerini kaybetmekte ya da unutmaktadır. Bunun tazelenmesi, tekrar bilinçlendirilmesi gerektiğini düşünüyorum.

Tablo 4. Türk dili ve edebiyatı öğretmeni adaylarının Karakter ve Değerler Ĕ̆itimi dersinin üniversitelerde lisans programlarında yer alması ile ilgili görüşlerinin analizi neticesinde ulaşılan kategoriler

\begin{tabular}{llll}
\hline & Kategoriler & $f$ & $\mathbf{\%}$ \\
\hline $\begin{array}{l}\text { Karakter ve Değerler } \\
\text { Eğitimi dersinin Lisans }\end{array}$ & $\begin{array}{l}\text { Evet, kesinlikle yer alması gerektiğini düşünüyo- } \\
\text { programlarında yer al- }\end{array}$ & 45 & 76,27 \\
$\begin{array}{l}\text { rum. } \\
\text { ması ile ilgili görüş̧leri- } \\
\text { niz nelerdir? }\end{array}$ & $\begin{array}{l}\text { Lisans programlarında yer alması faydalı olabilir } \\
\text { ama üniversiteden önceki eğitim kademelerinde } \\
\text { verilmesi çok daha önemlidir. }\end{array}$ & 11 & \\
\cline { 2 - 4 } & Gönüllük esasına dayalı olarak yer alabilir. & 2 & 3,38 \\
\cline { 2 - 4 } & Bu dersin lisans seviyesinde yer almaması gerekir. & 1 & 1,69 \\
\cline { 2 - 4 } & Toplam & $\mathbf{5 9}$ & $\mathbf{1 0 0}$ \\
\hline
\end{tabular}

Tablo 4'e geri dönüldüğünde; Türk dili ve edebiyatı öğretmeni adaylarını \%18,64'ünün Karakter ve Değerler Eğitimi dersinin üniversitelerde lisans programlarında yer almasına yönelik "lisans programlarında yer alması faydalı olabilir ama üniversiteden önceki eğitim kademelerinde verilmesi çok daha önemlidir" şeklinde görüş belirttikleri görülmektedir. Bu kategoride yer alan bazı öğretmen adayı görüşleri aşağıda verilmiştir:

- $\quad \ddot{O A-1: ~ B u ~ e g ̆ i t i m i n ~ i l k o k u l l a r d a n ~ b e r i ~ v e r i l m e s i ~ g e r e k t i g ̆ i n e ~ i n a n ı y o r u m . ~ L i-~}$ sans programlarında verilmesi çok güzel fakat geç kalınmış bir eğitim diye düşünüyorum.

- ÖA-16: Üniversite lisans programında yer alması çok güzel bir düşünce bence ancak üniversiteden önce lisede veya ortaokulda da bu dersin olması hiç şüphesiz daha güzel olacaktır.

Tablo 4'te; Türk dili ve edebiyatı öğretmeni adaylarının \%3,38'inin Karakter ve Değerler Eğitimi dersinin üniversitelerde lisans programlarında 
yer almasına yönelik "gönüllük esasına dayalı olarak yer alabilir" şeklinde görüş belirttikleri görülmektedir. Bu kategoride sadece 2 öğretmen adayı görüşü yer almaktadır. Bu öğretmen adaylarına ait görüşler aşağıda verilmiştir:

- ÖA-33: Yer alabilir. Ama zorlayicı olmadan.

- ÖA-48: Biz bu dersi formasyon dersleri arasında seçmeli ders olarak almış bulunmaktayız. Bence bu ders diğer bölümlerde de seçmeli ders olarak alınmalı, insanlar çevreye karşı sorumluluklarını veya karakteristik yapılarını oluşturmalarında bu dersten yararlanmalidır.

Son olarak Tablo 4 tekrar incelendiğinde; Türk dili ve edebiyatı öğretmeni adaylarının \%1,69'unun Karakter ve Değerler Eğitimi dersinin üniversitelerde lisans programlarında yer almasına yönelik "bu dersin lisans seviyesinde yer almaması gerektiğini düşünüyorum" şeklinde görüş belirttiği görülmektedir. Bu kategoride sadece 1 öğretmen adayı görüşü yer almaktadır. Bu öğretmen adayına ait görüş ise aşağıda dikkatlere sunulmuştur:

- ÖA-22: Karakter ve Değerler eğitiminin lisans programlarında yer alması, karakter ve değerler eğitiminin içerdiği konuların daha erken yaşlarda yeterince benimsetilememesinden kaynaklı olduğu için geç kalınmış bir eğitim olarak görüyorum ve bu konuya kısmen olumsuz bir durum olarak bakıyorum.

\section{Araştırmanın Dördüncü Alt Problemine İlişkin Bulgular}

Bu bölümde; Türk dili ve edebiyatı öğretmeni adaylarının, okullarda (ilkokul, ortaokul, lise) karakter ve değerler eğitimine yönelik eğitsel faaliyetlere yer verilmesi ile ilgili görüşlerini tespit etmek amaçlanmıştır. $\mathrm{Bu}$ bağlamda öğretmen adaylarından elde edilen verilerin analizi neticesinde, araştırmaya katılan tüm öğretmen adaylarının bu konuyla ilgili aynı fikirde oldukları görülmüştür. Dolayısıyla bu bölümde 1 kategori oluşturulmuştur. İlgili kategori ve buna ilişkin sonuçlar aşağıdaki tabloda gösterilmiştir: 
Tablo 5. Türk dili ve edebiyatı öğretmeni adaylarının okullarda (ilkokul, ortaokul, lise) karakter ve değerler eğitimine yönelik eğitsel faaliyetler verilmesi ile ilgili görüsslerinin analizi neticesinde ulaşılan kategoriler

\begin{tabular}{|c|c|c|c|}
\hline & Kategoriler & $f$ & $\%$ \\
\hline \multirow{2}{*}{$\begin{array}{l}\text { Okullarda karakter ve değerler eğiti- } \\
\text { mine yönelik eğitsel faaliyetlere yer } \\
\text { verilmesi ile ilgili görüşleriniz neler- } \\
\text { dir? }\end{array}$} & $\begin{array}{l}\text { Evet, kesinlikle yer } \\
\text { alması gerektiğini } \\
\text { düşünüyorum. }\end{array}$ & 59 & 100 \\
\hline & Toplam & 59 & 100 \\
\hline
\end{tabular}

Tablo 5 incelendiğinde, Türk dili ve edebiyatı öğretmeni adaylarının \%100'ünün okullarda (ilkokul, ortaokul, lise) karakter ve değerler eğitimine yönelik eğitsel faaliyetlere yer verilmesine yönelik "evet, kesinlikle yer alması gerektiğini düşünüyorum" şeklinde görüş belirttikleri görülmektedir. Bu doğrultuda öne çıan bazı öğretmen adayı görüşleri aşağıda dikkatlere sunulmuştur:

- ÖA-13: Bu değerlerin ilkokuldan başlanarak verilmesi gerekir. Çünkü karakter ve değerler eğitimi küçük yaş grubundan itibaren verilirse olumlu sonuç alma olasılığımı artar. Bunun sonucunda toplumda sağllklı bireyler olur.

- ÖA-25: Temeli sağlam olan bina çökmeyecektir. Toplumsal olarak bir çöküş istemiyorsak eğitimlerinde elbette küçük yaşlardan itibaren ilmek ilmek işlenmesi gerekir. Zira bu bir an meselesi değgil süreç işidir.

\section{Araştırmanın Beşinci Alt Problemine İlişkin Bulgular}

Bu bölümde; Türk dili ve edebiyatı öğretmeni adaylarının, Karakter ve Değerler Eğitimi dersinin değerlendirme ölçütlerinin neler olması gerektiği ile ilgili görüşlerini tespit etmek amaçlanmıştır. Bu bağlamda öğretmen adaylarından elde edilen verilerin analizi neticesinde, 6 farklı kategori oluşturulmuştur. İlgili kategoriler ve bunlara ilişkin sonuçlar aşağ1daki tabloda gösterilmiştir.

Tablo 6 incelendiğinde; Türk dili ve edebiyatı öğretmeni adaylarının \%71,18'inin Karakter ve Değerler Eğitimi dersinin değerlendirme ölçütlerinin neler olması gerektiğine yönelik "okul, aile ve sosyal hayatta; öğrencilerin davranışlarında ve tutumlarında meydana gelen değişiklikler dikkate alınmalı" şeklinde görüş belirttikleri görülmektedir. Bu doğrultuda öne çıkan bazı öğretmen adayı görüşleri aşağıda dikkatlere sunulmuştur: 
- $\quad$ ÖA-37: Teorik bilgiyi bilmesinden ziyade o bilgiyi yaşamında uygulayıp uygulamamasına yönelik değerlendirme yapılmalıdır. Öğrencinin sınıf içindeki davranışlar ve arkadaşlarıyla olan ilişkileri göz önünde tutularak değerlendirme yapilmalıdir.

- ÖA-31: Öğrencilerin davranışları gözlemlenerek değerlendirilmelidir. Çünkü bir kişinin nasıl biri olduğunu anlamak için o kişiyi gözlemlemek gerekir. Bir kimsenin sergilediği davranışlar onun kişiliğinin aynasıdır.

Tablo 6. Türk dili ve edebiyatı öğretmeni adaylarının Karakter ve Değerler Eğitimi dersinin değerlendirme ölçütlerinin neler olması gerektiği ile ilgili görüşlerinin analizi neticesinde ulaşılan kategoriler

\begin{tabular}{|c|c|c|c|}
\hline \multirow{2}{*}{\multicolumn{4}{|c|}{$\begin{array}{l}\text { Okul, aile ve sosyal hayatta; ögrencilerin davranışla- } \\
\text { rında ve tutumlarında meydana gelen değişiklikler } \\
\text { dikkate alınmalı. }\end{array}$}} \\
\hline \multirow{7}{*}{$\begin{array}{l}\text { Karakter ve } \\
\text { Değerler } \\
\text { Eğitimi der- } \\
\text { sinin değer- } \\
\text { lendirme öl- } \\
\text { çütleri sizce } \\
\text { neler olma- } \\
\text { lıdır? }\end{array}$} & & & \\
\hline & $\begin{array}{l}\text { Tek bir ölçütten bahsetmek zordur, birden fazla kriter } \\
\text { dikkate alınmalıdır. }\end{array}$ & 7 & 11,86 \\
\hline & $\begin{array}{l}\text { Uygulamalar ve performans değerlendirmeleri yapıl- } \\
\text { malı. }\end{array}$ & 6 & 10,16 \\
\hline & Sözlü veya yazılı sınava dayalı bir ölçme olmalı. & 2 & 3,38 \\
\hline & Öğrencilerin öz değerlendirmeleri dikkate alınmalı. & 1 & 1,69 \\
\hline & $\begin{array}{l}\text { Değerlendirme ölçütü, dersin verildiği eğitim kade- } \\
\text { mesine göre değişir }\end{array}$ & 1 & 1,69 \\
\hline & Toplam & 59 & 100 \\
\hline
\end{tabular}

Tablo 6'ya geri dönülecek olursa; Türk dili ve edebiyatı öğretmeni adaylarının \%11,86'sının Karakter ve Keğerler Eğitimi dersinin değerlendirme ölçütlerinin neler olması gerektiğine yönelik "tek bir ölçütten bahsetmek zordur, birden fazla kriter dikkate alınmalıdır" şeklinde görüş belirttikleri görülmektedir. Bu kategoride yer alan bazı öğretmen adayı görüşleri aşağıda verilmiştir:

- ÖA-5: Bir ölçüt belirlenmesi zordur. Gerçekten dersin kazanımlarmı edindiğini öğrenmek için bireyi her türlü sosyal bağlamda değerlendirmemiz gerekir. Sinavlarla bir ölçüt alamayız.

- ÖA-24: Bence çoktan seçmeli ile davranışı gözlemlemeyi aynı anda kullanmahıyı ki yazdıkları ile davranışların gözlemlersek aradaki o eksikliği bulabiliriz. Neden bunu yazıyor neden davranıslarında uygulamıyor gibi. 
Tablo 6'ya göre; Türk dili ve edebiyatı öğretmeni adaylarının \%10,16'sının Karakter ve Değerler Eğitimi dersinin değerlendirme ölçütlerinin neler olması gerektiğine yönelik "uygulamalar ve performans değerlendirmeleri yapılmalı" şeklinde görüş belirttikleri görülmektedir. Bu doğrultudaki bazı öğretmen adayı görüşleri aşağıda yer almaktadır:

- ÖA-32: Bence karakter ve değerler eğitimi performans değerlendirme ile değerlendirilmelidir.

- $\quad$ ÖA-33: İşlenilen konu ile ilgili olarak öğrencinin de içinde bulunduğu bir uygulama yaptırilabilir.

Tablo 6'ya bakıldığında; Türk dili ve edebiyatı öğretmeni adaylarının \%3,38'inin Karakter ve Değerler Eğitimi dersinin değerlendirme ölçütlerinin neler olması gerektiğine yönelik "sözlü veya yazılı sınava dayalı bir ölçme olmalı" şeklinde görüş belirttikleri görülmektedir. Bu kategoride sadece 2 öğretmen adayı görüşü yer almaktadır ki; bunlar aşağıda dikkatlere sunulmuştur:

- ÖA-18: Kesinlikle böyle bir dersin değerlendirme ölçütü bir sinav olamaz. Çünkü bu ders bir bilgi verilipte geri cevabı istenilebilecek bir ders değil. Çünkü toplumumuzu ilgilendiren konuları bünyesinde barındırıyor. Yazılı sinavdan ziyade sözlü bir sınav ya da karşılıklı konuşma olabilir.

- ÖA-54: Yazılı olarak değerlendirmelidir. Öğrenciler yazılı stnavlarda duygu ve düşüncelerini daha iyi ve açık ifade edebilirler.

Tablo 6'ya bakıldığında; Türk dili ve edebiyatı öğretmeni adaylarının \%1,69'unun Karakter ve Değerler Eğitimi dersinin değerlendirme ölçütlerinin neler olması gerektiğine yönelik "öğrencilerin öz değerlendirmeleri dikkate alınmalı" şeklinde görüş belirttiği görülmektedir. Bu kategoride sadece 1 öğretmen adayı görüşü yer almaktadır ki; bu görüşe aşağıda yer verilmiştir:

- ÖA-4: Bu ders için değgerlendirme öğrencilere kendilerini sorgulatmak olabilir. Yaptıkları doğru veya yanlış davranışlarını ölçmeleri istenilebilir.

Son olarak Tablo 6 tekrar incelendiğinde; Türk dili ve edebiyatı öğretmeni adaylarının \%1,69'unun Karakter ve Değerler Eğitimi dersinin değerlendirme ölçütlerinin neler olması gerektiğine yönelik "değerlendirme ölçütü, dersin verildiği eğitim kademesine göre değişir" şeklinde görüş belirttiği görülmektedir. Bu kategoride sadece 1 öğretmen adayı görüşü yer almaktadır ki; bu görüş aşağıda dikkatlere sunulmuştur: 
- ÖA-11: Yaş gruplarna göre bu ölçütlerin değişeceğini düşünüyorum. Öğretim seviyesi ilkokul olan bir öğrenci sinav yapılırken kendini yansitmak yerine öğretmenin takdirini alacak cevapları vermeyi tercih edebilir. O halde bu yaş gruplarının olaylar içerisinde davranışlarn incelenmelidir. Fakat lise dönemine gelmiş bir birey takdir edilme duygusunu birçok kez tattığı için ona bu konuda yapilan sinavlarda objektif olabilirler.

\section{Sonuç ve Tartışma}

Karakter ve Değerler Eğitimi dersine yönelik Türk dili ve edebiyatı öğretmeni adaylarının görüşlerini araştıran bu çalışmadan elde edilen sonuçlar aşağıda maddeler hâlinde dikkatlere sunulmuştur:

Araştırmanın birinci alt problemini "Türk dili ve edebiyatı öğretmeni adayları, karakter ve değerler eğitimini nasıl tanımlamaktadırlar?" sorusu oluşturmaktadır. Öğretmen adaylarının görüşlerinden elde edilen verilerin analizi neticesinde, bu alt probleme yönelik 4 farklı kategori oluşturulmuştur. Bu kategoriler arasında en çok katılımın olduğu kategori ise, $\% 50,84$ 'lük oranla "Bireyin dünyaya ve içinde bulunduğu topluma adapte olmasını sağlayan ve toplumu huzura ulaştıran bir eğitim süreci" kategorisidir. Yani araştırmaya katılan Türk dili ve edebiyatı öğrencilerinin $\% 50,84$ 'ü, karakter ve değerler eğitimini birey ve toplum arasında cereyan eden ve bireyin topluma uyumunu kolaylaştırarak sosyal yaşamı mümkün kılan bir süreç olarak görmektedirler. Literatür incelendiğinde, benzer sonuçlara başka araştırmalarda da rastlanılmaktadır. Bunlardan biri; Yıldırım ve Çalışkan'ın (2017), sosyal bilgiler öğretmenleri ile gerçekleştirdikleri ve öğretmenlerin değerlere ve değer eğitimine yönelik görüşlerini araştırdıkları çalışmadır. Yıldırım ve Çalışkan'ın çalışmalarının sonuçlarından biri de; araştırmaya katılan öğretmenlerin, değerler eğitiminin genç nesillerin yetiştirilmesinde, toplumsal düzenin sağlanmasında, toplumsal birlik ve beraberliğin sağlanmasında gerekli olduğunu ifade etmiş olmalarıdır. Öte taraftan Oğuz (2012) ise, kendi çalışmasında, öğretmen adaylarının en çok evrenselcilik, yardımseverlik, güvenlik gibi bireyler arası ilişkileri düzenleyen ve birey toplum uyumunu doğrudan etkileyen değerleri ön plana çıkardıklarını ifade etmiştir. Benzer şekilde Fırat (2007) ise, öğretmenlerin en çok benimsedikleri değerlerin; evrensellik, güvenlik, iyilikseverlik ve uyma değerleri 
olduğunu vurgulamıştır. Bu bağlamda literatürde benzer sonuçlara ulaşan araştırmalara; Akengin, Tuncel, Şirin ve Sargın (2009), Aktepe ve Yel (2009), Balcı ve Yanpar Yelken (2010), Taşdan (2008), Taşdan (2010), Turan ve Aktan (2008) çalışmalarını da eklemek mümkündür. Araştırmanın birinci alt problemine yönelik oluşturulan diğer kategorilerde ise; "İnsanın sahip olması gereken ahlaki ve vicdani bazı değerlerin öğretimi süreci" kategorisine \%30,50'lik, "Kimliğimizi ve benliğimizi korumanın olmazsa olmaz yolu" kategorisine $\% 16,94$ 'lük ve "İnsanı her yönüyle değerlendirme noktasında yeterli olmayan ve sadece ideali dile getiren bir yaklaşım" kategorisine de \%1,69'luk bir katılım gerçekleşmiştir.

Araştırmanın ikinci alt problemini "Türk dili ve edebiyatı öğretmeni adaylarının Karakter ve Değerler Eğitimi dersini seçme amaçları nelerdir?" sorusu oluşturmaktadır. Öğretmen adaylarının görüşlerinden elde edilen verilerin analizi neticesinde, bu alt probleme yönelik 7 farklı kategori oluşturulmuştur. Bu kategoriler arasında en çok katılımın olduğu kategori ise, \%35,59'luk oranla “Dersin kişisel gelişimine katkı sağlayacağı düşüncesi" kategorisidir. Yani araştırmaya katılan Türk dili ve edebiyatı öğrencilerinin \%35,59'u, Karakter ve Değerler Eğitimi dersinin kendi kişisel gelişimleri açısından faydalı olacağı kanaatindedir. Değerler eğitiminin bireylerin kişisel gelişimleri üzerindeki etkisi ile ilgili olarak Thornberg (2008), öğretmenlerin görüşlerine göre değerler eğitimi dersinin öğrencilerin iyi ve nazik davranışlara yönlendirilmesinde ve öğrencilerin sosyal beceriler kazanmasında etkili olduğunu ifade etmiştir. Öte taraftan Tezcan'a (2003) göre; değer eğitimi etkinlikleri, çocuğun iyi tarafının ortaya çıkmasını sağlamak, kişiliğini her yönüyle geliştirmek ve onun insani mükemmelliğe ulaşmasına yardımcı olmak amaçlarını taşır. Demirhan İşcan (2007), kendi araştırmasında, değerler eğitiminin öğrencilerin başarılarını da artırdığını ifade etmiştir. Yılmaz (2011) ise, bir anlamda değerler eğitimine hizmet eden Topluma Hizmet Uygulamaları dersinin öğretmen adaylarının toplumsal sorunların farkına varmasını sağladığını vurgulamıştır. Literatürde yer alan bu tür araştırmalar, değerler eğitimi dersinin bireylerin kişisel gelişimleri üzerindeki etkisine işaret etmesi bakımından manidardır. Araştırmanın ikinci alt problemine yönelik oluşturulan diğer kategorilerde ise; "Mesleki gelişimine katkı sağlama ve öğretmenlik hayatında kendi öğrencilerine faydalı olma 
düşüncesi" kategorisine \%33,89'luk, "Dersin isminin ilgi çekici olması ve içeriğine yönelik merak duygusu" kategorisine \%15,25'lik, "Dersin önemine ve gerekliliğine olan inanç" kategorisine \%10,16'llk bir katılım gerçekleşmiştir. "Arkadaşlarının da bu dersi seçmiş olması", "Kolay bir ders olduğunu düşünme" ve "Dersi tesadüfi bir şekilde seçme" kategorilerine ise, sadece $\% 1,69^{\prime}$ luk bir katılım olmuştur. Araştırmanın ikinci alt problemine yönelik oluşturulan kategorilerden en çok katılımın gerçekleştiği ikinci kategori olan "Mesleki gelişimine katkı sağlama ve öğretmenlik hayatında kendi öğrencilerine faydalı olma düşüncesi" kategorisine ayrıca değinmek yerinde olacaktır. Bu kategoride görüş belirten öğretmen adayları, karakter ve değerler eğitiminin mesleki gelişimlerine katkı sağlayacağını ve böylelikle öğretmenlik hayatlarında kendi öğrencilerine daha fazla katkı sağlayabileceklerini düşünmektedirler. Özellikle değer eğitiminde öğretmenlerin rol model olma sorumlulukları göz önüne alınırsa, bu bağlamda iyi yetişmiş bir öğretmenin ne kadar önemli olduğu daha iyi anlaşılabilir. Öğretmen adaylarının bu düşüncelerini destekleyici mahiyette sonuçların yer aldığı çalışmalar literatürde yer almaktadır. Yıldırım (2009), öğretmenlerin kişilik özellikleri açısından öğrenciye olumlu örnek teşkil etmesinin öneminin yadsınamayacağını ifade etmiştir. Benzer sonuçları Arthur (2003), Demirhan İşcan (2014), Ekşi ve Katılmış (2016), Katılmış ve Balcı (2017), Katılmış ve Kop (2016), Kurtdede Fidan (2009), Leming (2008), Lickona (1991) gibi başka çalışmalarda da görmek mümkündür.

Araştırmanın üçüncü alt problemini "Türk dili ve edebiyatı öğretmeni adaylarının Karakter ve Değerler Eğitimi dersinin üniversitelerde lisans programlarında yer almasına ilişkin görüşleri nelerdir?" sorusu oluşturmaktadır. Öğretmen adaylarının görüşlerinden elde edilen verilerin analizi neticesinde, bu alt probleme yönelik 4 farklı kategori oluşturulmuştur. Bu kategoriler arasında en çok katılımın olduğu kategori ise, $\% 76,27$ 'lik oranla "Evet, kesinlikle yer alması gerektiğini düşünüyorum" kategorisidir. Yani araştırmaya katılan Türk dili ve edebiyatı öğretmeni adaylarının \%76,27'si, Karakter ve Değerler Eğitimi dersinin üniversitelerde yer alması gerektiğini düşünmektedir. Başka bir ifade ile Türk dili ve edebiyatı öğretmeni adayları, üniversite öğrencilerinin değer eğitimi bağlamında yetersiz olduklarını düşünmektedirler. Araştırmanın bu sonucuna benzer sonuçlara literatürde de rastlanmaktadır. Örneğin; 
Yıldırım ve Çalışkan (2017), araştırmalarında, öğretmenlerin lisans eğitimleri süresince değerler eğitimine yönelik ders almamalarından yakındıklarını ifade ederek bu durumun öğretmenlerin değerler eğitimi konusunda yeterli donanıma sahip olmadıklarını gösterdiğini vurgulamıştır. Aynı şekilde Oğuz (2012) da kendi araştırmasında, öğretmen adaylarının değerler eğitimi noktasında yetersiz olduklarını ifade ederek bunun öğretmenlerin değerler eğitimi bağlaminda gerekli ve yeterli bir eğitim almadıklarının göstergesi olduğunu vurgulamıştır. Şahinkayası ve Kelleci (2012) ise; öğretmenlerin değerler eğitimine yönelik görüşlerini araştırdıkları çalışmalarında, araştırmaya katılan öğretmenlerin çoğunun değerler eğitimi ile ilgili herhangi bir eğitim almadıklarından dolayı meslek hayatlarında bu bağlamda yetersiz kaldıklarını ifade etmiştir. Benzer sonuçları Katılmış ve Balcı'nın (2017) coğrafya öğretmeni adayları ile gerçekleştirdiği çalışmalarında da görmek mümkündür. Katılmış ve Balcı, çalışmalarında, öğretmen adaylarının değerler eğitimi konusunda kendilerini yetersiz gördüklerini ve bunun da değerler eğitimi ile ilgili lisans eğitimlerinde herhangi bir eğitim almamalarına bağladıkların ifade etmişlerdir. Oysa Thorberg'in (2008) de ifade ettiği gibi değerler eğitimi konusunda yeterli bilgi ve donanıma sahip olmayan öğretmenlerin, bu bağlamda başarılı olmalarını beklemek hayalcilikten başka bir şey değildir. Araştırmanın üçüncü alt problemine yönelik oluşturulan diğer kategorilerde ise; "Lisans programlarında yer alması faydalı olabilir ama üniversiteden önceki eğitim kademelerinde verilmesi çok daha önemlidir" kategorisine \%18,64'lük, “Gönüllük esasına dayalı olarak yer alabilir" kategorisine \%3,38'lik ve "Bu dersin lisans seviyesinde yer almaması gerekir" kategorisine de \%1,69'luk bir katılım gerçekleşmiştir.

Araştırmanın dördüncü alt problemini “Türk dili ve edebiyatı öğretmeni adaylarının okullarda (ilkokul, ortaokul, lise), karakter ve değerler eğitimine yönelik eğitsel faaliyetlere yer verilmesine ilişkin görüşleri nelerdir?" sorusu oluşturmaktadır. Öğretmen adaylarının görüşlerinden elde edilen verilerin analizi neticesinde, araştırmaya katılan tüm öğretmen adaylarının bu konuda aynı fikirde oldukları görülmüş ve araştırmanın bu alt problemine yönelik 1 kategori oluşturulmuştur. \%100'lük katılımın gerçekleştiği bu kategori "Evet, kesinlikle yer alması gerektiğini düşünüyorum" kategorisidir. Yani araştırmaya katılan Türk dili ve edebiyatı öğretmeni adaylarının tamamı, Karakter ve Değerler 
Eğitimi dersine yönelik eğitsel faaliyetlerin üniversiteden önceki tüm eğitim kademelerinde yer alması gerektiğini düşünmektedir. Araştırmanın bu sonucuna benzer bir açıklama MEB tarafından 2017 yılında yayınlanan Sosyal Bilgiler Öğretim Programı'nda da yapılmıştır. MEB, kültürel hedeflere ulaşma ve kültürel devamlılığı sağlama noktasında, okullarda değerler eğitimi verilmesinin son derece önemli olduğunu vurgulamıştır. Aynı şekilde Çengelci, Hancı ve Karaduman (2013), ilköğretimde tüm derslerde değerler eğitimine yer verilmesi gerektiğini ifade etmişlerdir. Öte taraftan Yıldırım ve Çalışkan (2017), araştırmalarında, okullarda verilmesi hayati öneme sahip olan değerler eğitiminin, çeşitli sebeplerden dolayı sekteye uğradığını ve etkin bir değerler eğitimi sürecinin işletilemediği sonuçlarına ulaşmışlardır. Ayrıca Yıldırım ve Çalışkan'ın ifade ettikleri bir başka sonuç ise, araştırmaya katılan öğretmenlerin ders programındaki değerler eğitiminin yetersiz olduğunu düşünmeleridir. Benzer sonuçlara, Balcı ve Yanpar Yelken (2013), Yapıcı ve Leblebiciler (2007), Berkant, Efendioğlu ve Sürmeli (2014) de kendi araştırmalarında ulaşmışlardır.

Araştırmanın beşinci alt problemini "Türk dili ve edebiyatı öğretmeni adaylarına göre; Karakter ve Değerler Eğitimi dersinin değerlendirme ölçütleri neler olmalıdır?" sorusu oluşturmaktadır. Öğretmen adaylarının görüşlerinden elde edilen verilerin analizi neticesinde, bu alt probleme yönelik 6 farklı kategori oluşturulmuştur. Bu kategoriler arasında en çok katılımın olduğu kategori ise, \%71,18'lik oranla “Okul, aile ve sosyal hayatta; öğrencilerin davranışlarında ve tutumlarında meydana gelen değişiklikler dikkate alınmalı" kategorisidir. Yani araştırmaya katılan Türk dili ve edebiyatı öğretmeni adaylarının \%71,18'i, öğrencilerin tutum ve davranışlarından yola çıkılarak yapılacak bir ölçme ve değerlendirmenin, Karakter ve Değerler Eğitimi dersinin doğasına çok daha uygun olduğunu düşünmektedirler. Araştırmanın bu sonucuna benzer sonuçlara literatürde de rastlanmaktadır. Örneğin; Berkant, Efendioğlu ve Sürmeli (2014), sadece bilişsel değil duyuşsal yönü de ölçmeye yönelik araçların kullanılmasının gerekliliğine dikkat çekmiştir. Aynı şekilde Can Aran ve Demirel'in (2013) araştırmalarında da öğretmenlerin değerler eğitimi uygulamalarında öğrencilerin tutum ve davranışlarını gözlemleyerek bir ölçme gerçekleştirdikleri ifade edilmiştir. Nitekim Sönmez (2007) de değerlerin kazanılması duyuşsal alan davranışların ölçülmesinde 
öğrenci davranışlarını gözlemlemenin doğru bir yol olacağını vurgulamıştır. Araştırmanın beşinci alt problemine yönelik oluşturulan diğer kategorilerde ise; "Tek bir ölçütten bahsetmek zordur, birden fazla kriter dikkate alınmalıdır" kategorisine \%11,86'llk, "Uygulamalar ve performans değerlendirmeleri yapılmalı" kategorisine \%10,16'lık ve "Sözlü veya yazılı sınava dayalı bir ölçme olmalı" kategorisine de \%3,38'lik bir katılım gerçekleşmiştir. "Öğrencilerin öz değerlendirmeleri dikkate alınmalı" ve "Değerlendirme ölçütü, dersin verildiği eğitim kademesine göre değişir" kategorilerine ise sadece $\% 1,69^{\prime}$ luk bir katılım gerçekleşmiştir.

Araştırma verilerinden elde edilen sonuçlardan hareketle aşağıda sıralanan önerilere yer verilmiştir:

$\mathrm{Bu}$ araştırmadan elde edilen sonuçlar ve literatürdeki birçok araştırmada yer alan benzer sonuçlar, öğretmen adaylarının ve öğretmenlerin değerler eğitimi ile ilgili yeterli donanıma ve etkili bir değerler eğitimi süreci yönetebileceklerine olan öz yeterlik inancına sahip olmadıklarını göstermektedir. Öğretmen adayları ve öğretmenler, bu duruma sebep olarak ise, lisans eğitimleri süresince değerler eğitimi ile ilgili herhangi bir eğitim almamalarını göstermektedirler. Bu nedenle; değerler eğitimi noktasında yeterli bilgi ve donanıma sahip olmayan öğretmenlerin etkili bir değerler eğitimi gerçekleştiremeyeceği gerçeğini de göz önünde bulundururarak, üniversitelerde lisans bölümlerinde, özellikle de eğitim fakültelerinde, Karakter ve Değerler Eğitimi dersi zorunlu olarak verilmeli, hâlihazırda öğretmenlik görevini icra etmekte olan öğretmenler ise, değerler eğitimi bağlamında kurslara ve hizmet içi eğitimlere tabi tutulmalıdır.

Araştırmanın sonuçlarından biri de; öğretmen adaylarının, değerler eğitimi faaliyetlerinin eğitimin her kademesinde önem dikkat ve dikkatle icra edilmesi gerektiğine dair bir inanca sahip olmalarıdır. Bu sonuç, literatürde birçok çalışmada da yer almaktadır. Fakat literatürde yer alan bu çalışmalarda vurgulanan başka bir sonuç ise; okullarda çeşitli sebeplerden dolayı değerler eğitiminin istenilen düzeyde gerçekleştirilemediğidir. Okullarda verilmesi çok hassas bir konu olan değerler eğitiminin sağlıklı bir şekilde ilerlemesi için gerekli fiziksel, donanımsal ve psikolojik tedbirler alınmalı ve okullardaki değerler eğitimine yönelik eğitsel faaliyetlerin süresi ve yoğunluğu artırılmalıdır. 
Araştırmanın bir başka sonucuna göre; öğretmen adayları değerlerin kazanılması gibi duyuşsal alanla ilgili kazanımların edinilmesi konusunda ölçme aracı olarak öğrencilerin tutum ve davranışlarının gözlemlenmesi gerektiğini düşünmektedir. Bu sonuç literatürdeki başka çalışmalarla da örtüşmektedir. Fakat mevcut durumdaki uygulamalar, bu sonuçla pek de örtüşmemekte ve birçok öğretmen, bu bağlamda kullanılması gerekli olan ölçme araçları ve yöntemleri hakkında yeterli bilgiye sahip olmadıkları için değerler eğitimine yönelik ölçmelerini hâlâ klasik ölçme araçları vasıtasıyla yapmaktadır. Bu nedenle öğretmen adaylarına ve öğretmenlere duyuşsal alan kazanımlarının ölçülmesinde kullanabilecekleri ölçme yöntemleri konusunda dersler ve eğitimler verilerek, onların bu konudaki eksiklikleri giderilmelidir. 


\section{EXTENDED ABSTRACT}

\section{Examination of The Views of Turkish Language and Literature Teacher Candidates on Character and Value Education Course \\ *

\author{
Nurullah Şahin \\ A ̆gr İbrahim Cecen University
}

Although the concept of value has been a subject that scientists have been thinking about and researching for many years, issues such as value and value education have become increasingly popular, especially in recent years. The collapse of today's societies in areas such as belief, history, spirituality, national consciousness, etc. and societies' concerns about the ability to transfer their genetic codes, i.e. ancient values, to the future generations, have brought with them the popularization of the value subject and the necessity to ponder about it.

Depressions and predicaments experienced by the modern people are important reasons for the value education gaining importance today. Indeed, the lives of those who are deprived of values are not only dragging themselves into disaster, but also the society in which they live.

One of the biggest problems of societies living in today's world is the issue of transferring their existence and culture to the future. Only societies that manage to pass on their culture and values to the younger generations will be able to exist in the future and guarantee their own survival. And this is only possible with an effective and planned value education.

Considering all these reasons, it can be expressed clearly that value education "should be included in all levels of education, and to this end, curriculum and educational processes must be prepared, which are created extremely precisely" (Şahin, 2017, p.61).

The aim of this study is to determine the views of Turkish language and literature teacher candidates about the Character and Value Education course. 
The descriptive survey model was used in the study, in which the qualitative research approach was adopted. The study group consists of 59 teacher candidates (35 females and 24 males), who chose the Character and Value Education course as an elective course in the Pedagogical Formation Program of Sinop University in the fall semester of 2018-2019 academic year. In this study, a semi-structured interview form consisting of 5 open-ended questions was used as a data collection tool.

Descriptive analysis technique was used to analyze the data obtained. Firstly, the data obtained were read and coded in detail. Then, categories were formed for each sub-problem according to the content of the data encoded. The results section of the study included some simple statistical information related to the categories created for each sub-problem, as well as the views of some teacher candidates who stood out regarding the categories by citing from them directly. The conclusion and discussion section of the study included the results obtained from the findings, the comparison of these results with the results obtained from other studies in the literature, and the suggestions made in accordance with the general logic obtained from all of these. The results obtained from the research are listed below:

The question "How do Turkish language and literature teacher candidates define Character and Value Education?" constitutes the first subproblem of the study. As a result of the analysis of the data obtained from the views of teacher candidates, 4 different categories were formed for this sub-problem. Among these categories, the category to which the most participants agreed is the "An education process which enables the individual to adapt to the world and the society and which brings peace to society" category with $50,84 \%$. In other words, $50.84 \%$ of the students consider character and value education as a process that takes place between the individual and the society, which makes social life possible by facilitating the adaptation of the individual to society. When the literature is examined, similar results were encountered in the studies of Akengin, Tuncel, Sirin and Sargin (2009), Aktepe and Yel (2009), Balcı and Yanpar Yelken (2010), Firat (2007), Oğuz (2012), Taşdan (2008), Taşdan (2010), Turan and Aktan ( 2008) and Yıldırım and Çalışkan (2017). In the other categories created for the first sub-problem of the research, $30.50 \%$ of the participants agreed to "The process of teaching some moral and conscientious values 
that human beings should have" category; $16.94 \%$ agreed to "The essential way to protect our identity and self" category; and 1.69\% agreed to "An approach which is insufficient in evaluating every aspect of the human and which expresses only the ideal" category.

The question "What are the aims of the Turkish language and literature teacher candidates in choosing the Character and Value Education course?" constitutes the second sub-problem of the study. 7 different categories were created for this sub-problem as a result of the analysis of the data obtained from the opinions of teacher candidates. Among these categories, the category to which the most participants agreed is "The idea that the course would contribute to their personal development" category with $35.59 \%$. In other words, $35.59 \%$ of Turkish language and literature students who participated in the research believe that Character and Value Education course will be beneficial for their own personal development. This result of the research is also supported in the literature by the studies of Thornberg (2008), Tezcan (2003), Demirhan İşcan (2007) and Yilmaz (2011). In the other categories created for the second sub-problem of the research, $33.89 \%$ of the participants agreed to "Contribution to professional development and the idea of being useful to their students in teaching life" category; $15.25 \%$ agreed to "The name of the course being interesting and a sense of curiosity for its content" category; and 10.16\% agreed to "The belief in the importance and necessity of the course" category. Only $1.69 \%$ of participants agreed to the categories: "Because his/her friends had chosen this course", "Thinking that it was an easy course" and "Choosing the course by chance".

The question "What are the opinions of the Turkish language and literature teacher candidates on participating in Character and Values Education course in undergraduate programs in universities?" constitutes the third sub-problem of the study. As a result of the analysis of the data obtained from the views of teacher candidates, 4 different categories were formed for this sub-problem. Among these categories, the category to which the most participants agreed is the "Yes, I definitely think that it should be included" category with $76.27 \%$. In other words, $76.27 \%$ of the Turkish language and literature teacher candidates who participated in the study think that Character and Value Education course should be given in universities. Put differently, Turkish language and literature 
teacher candidates think that university students are not at a sufficient level in terms of value education. Similar results to the results of this study were also found in the studies of Yıldırım and Çalışkan (2017), Oğuz (2012), Şahinkayası and Kelleci (2012), Katılmış and Balcı (2017) and Thorberg (2008). In the other categories created for the third sub-problem of the research, $18.64 \%$ of the participants agreed to "It may be useful to include it in undergraduate programs, but it is much more important to give it at levels of education before the university" category; $3.38 \%$ agreed to "It may be included on a voluntary basis" category; and $1.69 \%$ agreed to "This course should not be given at the undergraduate level" category.

The question "What are the views of the Turkish language and literature teacher candidates on the inclusion of educational activities related to Character and Value Education in schools (Primary School, Secondary School, High School)?" constitutes the fourth sub-problem of the study. As a result of the analysis of the data obtained from the opinions of the teacher candidates, it was seen that all the teacher candidates agreed on this subject and 1 category was created for this sub-problem of the research. The category to which $100 \%$ of the participants agreed is the "Yes, I definitely think that it should be included" category. In other words, all of the Turkish language and literature teacher candidates who participated in the research think that the educational activities for Character and Value Education course should be included in all the education levels before the university. Similar results were also encountered in the studies of Çengelci, Hancı and Karaduman (2013), Yıldırım and Çalışkan (2017), Balcı and Yanpar Yelken (2013), Yapıcı and Leblebiciler (2007), Berkant, Efendioğlu and Sürmeli (2014).

The question "According to Turkish language and literature teacher candidates, what should be the evaluation criteria for the Character and Value Education course?" constitutes the fifth sub-problem of the study. As a result of the analysis of the data obtained from the views of teacher candidates, 6 different categories were formed for this sub-problem. Among these categories, the category to which the most participants agreed is the "In school, family and social life, changes in students' behaviors and attitudes should be taken into account" category with $71.18 \%$. In other words, $71.18 \%$ of Turkish language and literature teacher candidates 
think that a measurement and evaluation based on the attitudes and behaviors of students is much more appropriate to the nature of the Character and Values Education course. Similar results to this result of the study in the literature are also seen in the studies of Berkant, Efendioğlu and Sürmeli (2014), Can Aran and Demirel (2013) and Sönmez (2007). In the other categories created for the fifth sub-problem of the research, $11.86 \%$ of the participants agreed to "It is difficult to talk about a single criterion, multiple criteria must be taken into account" category; $10.16 \%$ agreed to "Applications and performance assessments should be carried out" category; and 3.38\% agreed to "There must be an assessment based on an oral or written exam." category. Only $1.69 \%$ of the participants agreed to the "Students' self-assessments should be taken into account" and "The assessment criteria vary according to the level of education in which the course is given" categories.

\section{Kaynakça / Reference}

Akengin, H., Tuncel, G., Şirin, A., ve Sargın, S. (2009). A comparative study on value ranking of the Turkish teaching department students in two universities. College Student Journal [Part B], 43 (4), 1191-1203.

Aktepe, V. ve Yel, S. (2009). İlköğretim öğretmenlerinin değer yargılarının betimlenmesi: Kırşehir ili örneği. Türk Eğitim Bilimleri Dergisi, 7 (3), 607-622.

Alyılmaz, C. ve Alyılmaz, S. (2014). Amirbek Turatoviç Muratov'dan Yenisey'e sesleniş. Uluslararası Türkçe Edebiyat Kültür Ĕ̆itim Dergisi. $3(1), 68-84$.

Alyılmaz, S. (2008). Öğretmen adaylarına göre görgü kurallarına aykırı davranışlar. İzvestiya Vuzov, 1-2, 136-142.

Arslantürk, Z. ve Arslantürk, A. (2013). Uygulamal sosyal araştırma: kavramlar, teknikler, metotlar, bilgisayar uygulamalar, SPSS. (3. Bsm), İstanbul: Çamlıca Yayınları.

Arthur, J. (2003). Educatin with character. London: RoutledgeFalmer. 
Balc1, F. A. ve Yanpar-Yelken, T. (2013). İlköğretim sosyal bilgiler programında yer alan değerler ve değer eğitimi uygulamaları konusunda öğretmen görüşleri. Ahi Evran Üniversitesi Kırşehir Ĕ̆itim Fakültesi Dergisi (KEFAD), 14( 1), 195-213.

Balc1, A. ve Yanpar-Yelken, T. (2010). İlköğretim öğretmenlerinin değer kavramina yüklediği anlamlar. Hacettepe Üniversitesi Ĕ̆itim Fakültesi Dergisi, 39, 81-90.

Beil, B. (2003). İyi çocuk, zor çocuk, 'doğru davranışlar çocuklara nasıl kazandırılır? (C. Yorulmaz Çev.). Ankara: Arkadaş Kitapevi.

Berkant, H. G., Efendioğlu, A. ve Sürmeli, Z. (2014). Değerler eğitimine yönelik öğretmen görüşlerinin incelenmesi. International Periodical For The Languages, Literature and History of Turkish or Turkic, 9(5), 427-440.

Can-Aran, Ö. ve Demirel, Ö. (2013). Dördüncü ve beşinci sınıf öğretmenlerinin sosyal bilgiler dersinde değerler eğitimi uygulamalarına ilişkin görüşleri. Elektronik Sosyal Bilimler Dergisi, 12(46), 151-168.

Çengelci, T. Hancı, B. ve Karaduman, H. (2013). Okul ortamında değerler eğitimi konusunda öğretmen ve öğrenci görüşleri. Değerler Eğitimi Dergisi, 11(25), 33-56.

Demirhan İşcan, C. (2014). Öğretmen adaylarının değerler eğitimindeki tercihleri. İlköğretim Online, 13(4), 1203-1222.

Demirhan-İşcan, C. (2007). İlköğretim düzeyinde değerler eğitimi programının etkililiği. Yayımlanmamış doktora tezi, Hacettepe Üniversitesi, Sosyal Bilimler Enstitüsü, Ankara.

Doğan, H. (1997). Eğitimde program ve öğretim tasarımı. Ankara: Önder Matbaacilik.

Ekşi, H. ve Katılmış, A. (2016). Uygulama örnekleriyle değerler eğitimi. Ankara: Nobel.

Er, O. (2017). Suha Mermerci'nin Kitaplarının Kültürel Değerler Açısından Değerlendirilmesi. Uluslararası Türkçe Edebiyat Kültür Ĕğitim Dergisi, 6(2), 1178-1188.

Fırat, N. (2007). Okul kültürü ve öğretmenlerin değer sistemleri. Yayımlanmamış doktora tezi. Dokuz Eylül Üniversitesi. Eğitim Bilimleri Enstitüsü. İzmir.

Kale, N. (2004). Nasıl bir değerler eğitimi? Değerler ve Eğitimi Uluslararası Sempozyumu'nda sunulan bildiri, İstanbul. 
Katılmış, A. ve Balcı, A. (2017). Coğrafya öğretmeni adaylarının değer eğitimine yönelik görüşlerinin incelenmesi. Marmara Coğrafya Dergisi, 35, 1-12.

Katılmış, A. ve Kop, Y. (2016). Sosyal bilgiler öğretmeni adaylarının değerler eğitimine ilişkin görüşleri. (M. Kocak Ed.), Hoca Ahmet Yesevi Yılı Anısına Uluslararası Türk Dünyası Eğitim Bilimleri ve Sosyal Bilimler Kongresi Bildiriler Kitabı içinde (s. 223-238). Ankara.

Kavcar, C. (1999). Edebiyat ve eğitim. (3. Bsm). Ankara: Engin Yayıncllık.

Köktürk, M. (2006). Kültürün dünyası, kültür felsefesine giriş. Ankara: Hece Yayıncilik.

Kurtdede-Fidan, N. (2009). Öğretmen adaylarının değer öğretimine ilişkin görüşleri. Kuramsal Eğitimbilim Dergisi, 2(2), 1-18.

Lambert, V. A. ve Lambert, C. E. (2012). Qalitative descriptive research: an acceptable design. Pasific Rim International Journal of Nursing Research, 16 (4), 255-256.

Leming, J. S. (2008). Research and practice in moral and character education: loosely coupled phenomena. In (L. P. Nucci ve D. Narvaez eds.), Handbook Of Moral And Character Education (s.134-161). London and New York: Routledge, Taylor and Francis Group.

Lickona, T. (1991). Educating for character: How school can teach respect and responsibility. New York: Battam.

MEB, (2017). Sosyal bilgiler öğretimi programı. Ankara.

Miles, M. B. ve Huberman, A. M. (1994). Qualitative data analysis. Thousand Oaks, CA: Sage Publication.

Oğuz, E. (2012). Öğretmen adaylarının değerler ve değerler eğitimine ilişkin görüşleri. Kuram ve Uygulamada Eğitim Bilimleri. 12 (2), 13091325.

Sönmez, V. (2007). Öğretmen el kitabı. Ankara: Anı Yayıncılık.

Şahin, N. (2017). Cengiz Aytmatov'un eserlerinin değerler eğitimi bağlamında incelenmesi ve ortaokul Türkçe ders kitapları için metin önerileri. Yayınlanmamış Doktora Tezi, Atatürk Üniversitesi Eğitim Bilimleri Enstitüsü, Erzurum.

Şahinkayası, Y. ve Kelleci, Ö. (2012). Elementary school teachers' Views on values education. Procedia Social and Behavioral Sciences, 93, 116120. 
Taşdan, M. (2008). Kamu ve özel ilköğretim okullarında görevli öğretmenlerin değer, iş doyumu ve öğretmene mesleki sosyal destek ile ilgili görüşleri. Yayımlanmamış doktora tezi, Ankara Üniversitesi, Eğitim Bilimleri Enstitüsü, Ankara.

Taşdan, M. (2010). Türkiye'deki resmi ve özel ilköğretim okulu öğretmenlerinin bireysel değerleri ile okulun örgütsel değerleri arasındaki uyum düzeyi. Kuram ve Uygulamada Ĕ̆itim Yönetimi, 16 (1), 113148.

Tezcan, M. (2003). Gizli müfredat eğitim sosyolojisi açısından bir kavramasal çözümlemesi. Türk Ĕ̆itim Bilimleri Dergisi, 1 (1), 53-59.

Thornberg, R. (2008). The lack of professional knowledge in values education. Teaching and Teacher Education: An International Journal of Research and Studies, 24 (7), 1791-1798.

Turan, S. ve Aktan D. (2008). Okul hayatında var olan ve olması düşünülen sosyal değerler. Türk Eğitim Bilimleri Dergisi, 6 (2), 227-259.

Walker, R. (2012). Naturalistic research.. In (Ed. J. Arthur, M. Woring, R. Coe and L. V. Hedges.). Research Methods and Methodologies in Education (s. 76-93). California: SAGE.

Yıldırım, Y. ve Çalışkan, H. (2017). 2005 ile 2017 sosyal bilgiler dersi öğretim programlarındaki değerlere ve değerler eğitimine ilişkin öğretmen görüşleri. Journal of Multidisciplinary Studies in Education, $1(1), 7-23$.

Yıldırım, K. (2009). Values education experiences of Turkish class teachers: A phenomonological approach. Ĕ̆itim Araştırmaları-Eurasian Journal of Educational Research, 35, 165-184.

Yıldırım, A. ve Şimşek, H. (2005). Sosyal bilimlerde nitel araştırma yöntemleri (5. Bsm.). Ankara: Seçkin Yayınevi.

Yılmaz, K. (2011). Eğitim fakültelerinin sosyal sorumluluğu ve topluma hizmet uygulamaları dersi: Nitel bir araştırma. Kuramsal Ĕ̆itimbilim, 4 (2), 86-108. 


\section{Kaynakça Bilgisi / Citation Information}

Şahin, N. (2019). Türk dili ve edebiyatı öğretmeni adaylarının karakter ve değerler eğitimi dersine yönelik görüşlerinin incelenmesi. OPUSUluslararası Toplum Araştırmaları Dergisi, 11(18), 1058-1090. DOI: 10.26466/opus. 569630 